\title{
“JOKOWI EFFECT” PADA INDEKS HARGA SAHAM GABUNGAN
}

\author{
Muhit Nur Hidayah ${ }^{1}$ \\ Statistisi Badan Pusat Statistik Kabupaten Sragen \\ Mahasiswa Magister Ekonomi Program Pascasarjana UNS \\ email : muhit@bps.go.id
}

\begin{abstract}
The purpose of this study is to examine the effect of "Jokowi Effect" to abnormal stock return of companies included IHSG during 2014m1 to $2018 \mathrm{~m} 3$ before and after the inauguration of Joko Widodo become President of Republic of Indonesia. Event announcements that Jokowi become a presidential candidate on 2014 touted affecting Indonesian capital market. Then the event is known as the effect of Jokowi is information that can be reacted in the capital market. The results of this research found that events of the announcements that Jokowi become a presidential candidate on 2014 have the information content. Variable exchange rate, kurs, interest rate, and dummy (after and before the events of the announcements that Jokowi become a presidential candidate on 2014) significant affect IHSG. The tests showed that the value of F test with p-value $0.000168<0.05$.
\end{abstract}

Keyword : dummy, Jokowi effect, IHSG.

Abstraksi. Tujuan dari penelitian ini adalah untuk mengetahui pengaruh "Jokowi Effect" terhadap IHSG selama kurun waktu bulan Januari 2014 sampai Maret 2018. Kurun waktu ini adalah masa sebelum dan sesudah pengumuman kabinet kerja Jokowi. Pengumuman kabinet Jokowi pada 2014 disebut-sebut mempengaruhi pasar modal Indonesia. Maka peristiwa ini disebut "Jokowi Effect", dimana peristiwa ini akan mempengaruhi pasar modal. Hasil penelitian ini menunjukkan bahwa Peristiwa pengumuman Kabinet Kerja Jokowi tahun 2014 berpengaruh terhadap IHSG, selain itu variabel lain seperti nilai tukar, kurs dan dummy berpengaruh significant terhadap IHSG, hal ini ditunjukan dari hasil F test dengan nilai p-value 0,000168 <0,05.

Kata kunci: dummy, Jokowi effect, IHSG.

\section{PENDAHULUAN}

Pasar modal merupakan salah satu alternatif pilihan investasi yang dapat menghasilkan tingkat keuntungan optimal bagi investor. Investasi dapat diartikan sebagai suatu kegiatan menempatkan dana pada satu atau lebih dari satu aset selama periode tertentu dengan harapan dapat memperoleh penghasilan dan peningkatan nilai investasi (Husnan, 2000). Setiap investor di pasar modal sangat membutuhkan informasi yang relevan dengan perkembangan transaksi di bursa, hal ini sangat penting untuk dijadikan referensi dan bahan pertimbangan dalam pengambilan keputusan investasi dipasar modal.

Pasar modal juga memiliki peran yang cukup besar dalam perekonomian suatu negara. Hal ini dikarenakan pasar modal menjalankan dua fungsi sekaligus, yaitu fungsi ekonomi dan fungsi keuangan. 
Disebut fungsi ekonomi karena pasar modal mampu menyediakan fasilitas yang mempertemukan dua kepentingan, yaitu pihak yang kelebihan dana dan pihak yang memerlukan dana. Pasar modal juga berfungsi sebagai fungsi keuangan karena pasar modal memberikan kesempatan memperoleh imbalan (return) bagi pemilik dana, sesuai dengan karakteristik yang dipilih (Suta, 2000 dalam Susanti 2015).

Untuk melihat perkembangan pasar modal Indonesia salah satu indikator yang sering digunakan adalah Indeks Harga Saham Gabungan (IHSG), yang merupakan salah satu indeks pasar saham yang digunakan oleh Bursa Efek Indonesia (BEI). Indikator pasar modal ini dapat berfluktuasi seiring dengan perubahan indikator-indikator makro yang ada. Seiring dengan indikator pasar modal, indikator ekonomi makro juga bersifat fluktuatif.

IHSG merupakan nilai yang digunakan untuk mengukur kinerja gabungan seluruh saham (perusahaan/emiten) yang tercatat di Bursa Efek Indonesia (BEI). Pergerakan IHSG dipengaruhi oleh beberapa faktor, diantaranya faktor dalam negeri dan faktor luar negeri. Pengaruh faktor luar negeri diantaranya adanya pengaruh dari indeks bursa asing negara lain (Dow Jones, Hang Seng, Nikkei,dll), tren perubahan harga minyak dunia, tren harga emas dunia, sentimen pasar luar negeri, dan lain sebagainya. Sedangkan faktor yang berasal dari dalam negeri bisa datang dari nilai tukar atau kurs di suatu negara terhadap negara lain, tingkat suku bunga dan inflasi yang terjadi di negara tersebut, kondisi sosial dan politik suatu negara, jumlah uang beredar dan lain sebagainya.

Salah satu faktor internal dalam negeri adalah peristiwa politik. Peristiwa politik berkaitan erat dengan stabilitas perekonomian suatu negara. Kondisi politik yang stabil cenderung meningkatkan kinerja ekonomi suatu negara. Hal ini dikarenakan tingkat resiko kerugian yang diakibatkan oleh faktor non ekonomi, sehingga adanya peristiwa politik yang mengancam stabilitas negara, seperti pemilihan umum, pergantian kepala negara, ataupun berbagai kerusuhan politik, cenderung mendapat respon dari pelaku pasar. (Husnan, 2005 dalam Susanti 2015) menjelaskan bahwa kondisi politik yang stabil akan ikut membantu pertumbuhan ekonomi yang pada akhirnya memengaruhi supply dan demand akan sekuritas.

Peristiwa politik di Indonesia identik dengan peristiwa lima tahunan atau saat bergantinya kepemimpinan pemerintahan. Pergantian ini di tandai dengan berlangsungnya pemilihan langsung (Pemilu) presiden dan wakil presiden. Pada tanggal 09 April 2014 dilakukan pemilu dengan dua pasang calon presiden dan wakil presiden. Pertama adalah pasangan Prabowo dari Partai Gerindra dan Hatta Rajasa dari Partai Amanat Nasional. Sementara di nomor urut dua merupakan pasangan dari PDIP-P Joko Widodo (Jokowi) dan Jusuf Kalla (JK) dari Golkar. Kedua pasangan ini memiliki basis massa yang sama-sama kuat. Dan berpotensi sama untuk memenangkan Pilpres 2014. Hasil akhir dari pemilu dimenangkan oleh pasangan Joko Widodo (Jokowi) dan Jusuf Kalla (JK).

Setelah terpilih menjadi Presiden, pasar keuangan bergerak menguat setelah Joko Widodo dilantik sebagai presiden Republik Indonesia ketujuh. Tercatat bahwa mulai tanggal 17 Oktober (H-3 Sebelum Pelantikan) terjadi penguatan rupiah hingga 151 poin $(1,23 \%)$ menjadi 
Rp 12.110 per dollar AS, IHSG naik 77,33 poin $(1,56 \%)$ ke $5.028,95$, dilanjut pada tanggal 20 Oktober 2014, yaitu pada hari pelantikan Presiden Republik Indonesia, indeks harga saham gabungan di Bursa Efek Indonesia ditutup menguat sebesar 12 poin $(0,23 \%)$ ke level $5.040,532$, dan rupiah menguat 78 poin $(0,64 \%)$ ke level Rp 12.032 per dollar Amerika Serikat. (Koran Tempo: 21 Oktober 2014). Adanya penguatan baik dari sisi rupiah, dan IHSG merupakan reaksi dari pasar yang mempunyai ekspektasi atau harapan terjadinya peningkatan pertumbuhan ekonomi setelah presiden Jokowi dilantik.

Pengumuman Kabinet Kerja Joko Widodo memengaruhi keputusan para investor. Apabila investor memanfaatkan informasi tersebut, maka pengumuman tersebut akan memengaruhi perubahan IHSG. Berdasarkan latar belakang tersebut penelitian ini mengkaji tentang pengaruh pengumuman kabinet kerja Jokowi terhadap IHSG dan juga pengaruh kurs, inflasi, tingkat suku bunga SBI terhadap IHSG.

Penelitian terdahulu dilakukan oleh Anisa Susanti (2015), mengenai “Analisis Pengaruh Kemenangan Pasangan Joko Widodo Jusuf Kalla dalam Pilpres 2014 terhadap Abnormal Return dan Trading Volume Activity pada Kelompok Saham Indeks LQ45". Hasil penelitian menunjukkan terdapat perbedaan signifikan rata-rata abnormal return sebelum dan nilai saat peristiwa serta ratarata abnormal return setelah dan saat peristiwa pengumuman kabinet kerja Jokowi. Namun tidak ada perbedaan signifikan ratarata abnormal return sebelum dengan setelah peristiwa. Terdapat perbedaan signifikan rata-rata trading volume activity sebelum dan saat peristiwa serta rata-rata trading volume activity setelah dan saat peristiwa. Namun tidak ada perbedaan signifikan antara ratarata trading volume activity sebelum dengan setelah peristiwa.

Sari (2015) melakukan penelitian tentang "Pengaruh Pengumuman Kabinet Kerja Joko Widodo terhadap Perubahan Reaksi Pasar Modal pada Perusahaan Manufaktur di Bursa Efek Indonesia". Hasil penelitian menunjukkan bahwa pergerakan abnormal return perusahaan manufaktur di Bursa Efek Indonesia sebelum dan sesudah pengumuman Kabinet Kerja Joko Widodo menunjukkan adanya pergerakan yang meningkat, yaitu rata-rata abnormal return sebelum pengumuman Kabinet Kerja Joko Widodo sebesar -0,02275164 meningkat menjadi 0,017958036 sesudah pengumuman. Peningkatan abnormal return tersebut menunjukkan bahwa pengumuman Kabinet Kerja Joko Widodo merupakan good news bagi investor sehingga berdampak pada peningkatan keepercayaan pelaku pasar terhadap pemerintah. Volume perdagangan saham sebelum dan sesudah pengumuman Kabinet Kerja Joko Widodo menunjukkan peningkatan aktivitas yaitu 0,000556767 menjadi 0,000571515. Peningkatan volume perdagangan saham tersebut menunjukkan bahwa pasar modal bereaksi terhadap informasi pengumuman Kabinet Kerja Joko Widodo.

Penelitian yang lain dilakukan oleh Shanty Oktavilia (2003), menggunakan analisis regresi berganda dimana PDB, kurs rupiah, tingkat suku bunga SBI, Indeks DJIA mempunyai pengaruh positif terhadap IHSG. Sedangkan suku bunga mempunyai pengaruh yang negatif terhadap IHSG.

Variabel yang digunakan dalam penelitian ini adalah nilai tukar, inflasi, 
suku bunga SBI dan dummy variabel sebelum dan sesudah pemerintahan Jokowi.

Nilai tukar Rupiah atau disebut juga kurs Rupiah adalah perbandingan nilai atau harga mata uang Rupiah dengan mata uang lain. Perdagangan antar negara dimana masing-masing negara mempunyai alat tukarnya sendiri mengharuskan adanya angka perbandingan nilai suatu mata uang dengan mata uang lainnya, yang disebut kurs valuta asing atau kurs (Salvatore, 1998:8 dalam Ardiono 2008).

Inflasi adalah kecenderungan dari harga-harga untuk naik secara umum dan terus menerus. Akan tetapi bila kenaikan harga hanya dari satu atau dua barang saja tidak disebut inflasi, kecuali bila kenaikan tersebut meluas atau menyebabkan kenaikan sebagian besar dari harga barangbarang lain. (Boediono, 1985:161 dalam Ardiono 2008).

Menurut Keynes, Suku bunga (Wardane, 2003 dalam Andrianto 2011), tingkat bunga ditentukan oleh permintaan dan penawaran akan uang (ditentukan dalam pasar uang). Perubahan tingkat suku bunga selanjutnya akan memengaruhi keinginan untuk mengadakan investasi, misalnya pada surat berharga, dimana harga dapat naik atau turun tergantung pada tingkat bunga (bila tingkat bunga naik maka surat berharga turun dan sebaliknya), sehingga ada kemungkinan pemegang surat berharga akan menderita capital loss atau capital gain.

Sedangkan SBI adalah sebagaimana tercantum dalam UU No. 23 Tahun 1999 tentang Bank Indonesia, salah satu tugas Bank Indonesia (BI) sebagai otoritas moneter adalah membantu pemerintah dalam mengatur, menjaga dan memelihara kestabilan nilai rupiah. Dalam melaksanakan tugasnya, BI menggunakan beberapa piranti moneter yang terdiri dari Giro Wajib Minimum (Reserve Requirement), Fasilitas Diskonto, Himbauan Moral dan Operasi Pasar Terbuka. Dalam Operasi Pasar Terbuka BI dapat melakukan transaksi jual beli surat berharga termasuk Sertifikat Bank Indonesia (SBI).

Dummy Variable adalah metode pengklasifikasian data yang membagi sebuah sampel menjadi beberapa subgrup berdasarkan kualitas atau atribut. Dalam penelitian ini dummy variables adalah masa sebelum pengumuman kabinet kerja Joko Widodo dan setelahnya. Nilai variabel dummy adalah sebagai berikut. Nilai $D=0$ untuk periode masa sebelum pengumuman kabinet kerja Joko Widodo dan nilai $\mathrm{D}=1$ untuk periode masa setelah pengumuman kabinet kerja Joko Widodo. Berdasarkan identifikasi di atas maka mulai periode 2014.m.11 dummy variabel bernilai 1 dan nilai dummy variabel periode selain itu bernilai 0 dikarenakan pengumuman kabinet kerja Joko Widodo pada bulan Oktober Tahun 2014.

Untuk mengukur kinerja saham yang diperdagangkan di bursa digunakan suatu indeks, yaitu Indeks Harga Saham Gabungan (IHSG). IHSG merupakan angka indeks harga saham yang sudah disusun dan dihitung sehingga menghasilkan trend, dimana angka indeks adalah angka yang diolah sedemikian rupa sehingga dapat digunakan membandingkan kejadian yang dapat berupa perubahan harga saham dari waktu ke waktu (Hismendi : 2013).

Adapun hipotesis-hipotesis yang diajukan dalam penelitian ini adalah sebagai berikut:

1. Diduga nilai tukar dolar Amerika (kurs) mempunyai pengaruh signifikan terhadap Indeks Harga 
Saham Gabungan (IHSG) di Bursa Efek Indonesia (BEI) tahun 2014.1 2018.3 sebelum dan setelah pengumuman kabinet kerja Joko Widodo.

2. Diduga inflasi mempunyai pengaruh signifikan terhadap Indeks Harga Saham Gabungan (IHSG) di Bursa Efek Indonesia (BEI) tahun 2014.1 2018.3 sebelum dan setelah pengumuman kabinet kerja Joko Widodo.

3. Diduga tingkat suku bunga SBI mempunyai pengaruh signifikan terhadap Indeks Harga Saham Gabungan (IHSG) di Bursa Efek Indonesia (BEI) tahun 2014.1 2018.3 sebelum dan setelah pengumuman kabinet kerja Joko Widodo.

Diduga peristiwa sebelum dan setelah pengumuman kabinet kerja Joko Widodo mempunyai pengaruh signifikan terhadap Indeks Harga Saham Gabungan (IHSG) di Bursa Efek Indonesia (BEI) tahun 2014.1 - 2018.3.

\section{METODE PENELITIAN}

Analisis Regresi linier (Linear Regression analysis) adalah teknik statistika untuk membuat model dan menyelidiki pengaruh antara satu atau beberapa variabel bebas (Independent Variables) terhadap satu variabel respon (dependent variable). Ada dua macam analisis regresi linier:

Regresi Linier Sederhana: Analisis Regresi dengan satu Independent variable, dengan formulasi umum:

$$
Y=a+b_{1} X_{1}+e
$$

1. Regresi Linier Berganda: Analisis regresi dengan dua atau lebih Independent Variable, dengan formulasi umum :

$$
\begin{aligned}
Y= & a+b_{1} X_{1}+b_{2} X_{2}+\ldots+b n X_{n} \\
& +e
\end{aligned}
$$

Dimana:

$\boldsymbol{Y}=$ Dependent variable

$\boldsymbol{a}=$ konstanta

$\boldsymbol{b}_{\mathbf{1}}=$ koefisien regresi $\mathrm{X} 1$,

$\boldsymbol{b}_{2}=$ koefisien regresi $\mathrm{X} 2$, dst.

$\boldsymbol{e}=$ Residual / Error

Fungsi persamaan regresi selain untuk memprediksi nilai Dependent Variable (Y), juga dapat digunakan untuk mengetahui arah dan besarnya pengaruh Independent Variable (X) terhadap Dependent Variable $(Y)$.

Asumsi yang harus terpenuhi dalam analisis regresi (Gujarati, 2003) adalah:

1. Residual menyebar normal (asumsi normalitas)

2. Antar Residual saling bebas (Autokorelasi)

3. Kehomogenan ragam residual (Asumsi Heteroskedastisitas)

4. Antar Variabel independent tidak berkorelasi (multikolinearitas)

Dalam penelitian ini, peneliti menggunakan metode deskriptif dan kuantitatif, yaitu mendiskripsikan suatu permasalahan dan menganalisis data dan hal-hal yang berhubungan dengan angkaangka atau rumus-rumus perhitungan yang digunakan untuk menganalisis masalah yang sedang diteliti.

Pemilihan Model Empirik dengan Mackinnon, White dan Davidson (uji MWD).

Penelitian ini menggunakan analisis regresi berganda dengan data runtut waktu (time series). Dalam analisis ini, sebelum menentukan akan menggunakan persamaan linier atau log linier maka harus mengetahui apakah prilaku data 
menunjukkan hubungan linier atau log linier dengan metode Mackinnon, white dan Davidson (uji MWD). Secara umum model persamaan linear dan log linier ditulis sebagai berikut :

$$
\text { Linier } \rightarrow Y=\beta_{0}+\beta_{1} X_{1}+\beta_{2} X_{2}+\beta_{3} X_{3}+\beta_{4} X_{4}
$$

$$
\log \text { Linier } \rightarrow \ln Y=\beta_{0}+\beta_{1} \ln X_{1}+\beta_{2} \ln X_{2}+
$$$$
\beta_{3} \ln X_{3}+\beta_{4} \ln X_{4}
$$

Adapun prosedur metode MWD adalah sebagai berikut :

1. Estimasi model linier dan dapatkan nilai prediksinya (fitted value) dan selanjutnya dinamai $\boldsymbol{F}_{\mathbf{1}}$.

2. Estimasi model log linier dan dapatkan nilai prediksinya, dan selanjutnya dinamai $\boldsymbol{F}_{\mathbf{2}}$.

3. Dapatkan nilai $\boldsymbol{Z}_{\mathbf{1}}=\boldsymbol{\operatorname { n n }} \boldsymbol{F}_{\mathbf{1}}-\boldsymbol{F}_{\mathbf{2}}$ dan $\boldsymbol{Z}_{\mathbf{2}}$ $=\operatorname{antilog} F_{2}-F_{2}$

4. Estimasi persamaan berikut ini

$$
Y=\beta_{0}+\beta_{1} X_{1}+\beta_{2} X_{2}+\beta_{3} X_{3}+\beta_{4} X_{4}
$$

Jika $Z_{1}$ signifikan secara statistik melalui uji $\mathrm{t}$ maka kita menolak hipotesis nol bahwa model yang benar adalah model linier dan sebaliknya jika tidak signifikan maka kita menerima hipotesis nol bahwa model yang benar adalah model linier.

5. Estimasi persamaan berikut ini:

$$
\begin{aligned}
\ln Y= & \beta_{0}+\beta_{1} \ln X_{1}+\beta_{2} \ln X_{2}+\beta_{3} \ln X_{3}+ \\
& \beta_{4} \ln X_{4}
\end{aligned}
$$

Jika $\boldsymbol{Z}_{\mathbf{2}}$ signifikan secara statistik melalui uji $\mathrm{t}$ maka kita menolak hipotesis alternatif dan model yang benar adalah model log linier dan sebaliknya jika tidak signifikan maka kita menerima hipotesis alternatif dan model yang benar adalah model log linier.

Model dasar penelitian ini adalah $Y=\beta_{0}+\beta_{1} X_{1}+\beta_{2} X_{2}+\beta_{3} X_{3}+\beta_{4} X_{4}$
$I H S G=\beta_{0}+\beta_{1} . K U R S+\beta_{2} . I N F L A S I$

$$
+\beta_{3} D U M M Y+\beta_{4} . S B I_{4}
$$

Keterangan :

$$
\begin{aligned}
\boldsymbol{Y}= & \text { IHSG (point) } \\
\boldsymbol{X}_{\mathbf{1}}= & \text { Kurs dollar US terhadap rupiah } \\
& \text { (rupiah) } \\
\boldsymbol{X}_{\mathbf{2}}= & \text { Inflasi }(\%) \\
\boldsymbol{X}_{\mathbf{3}}= & \text { Dummy } \\
\boldsymbol{X}_{\mathbf{4}}= & \text { Suku Bunga }(\%)
\end{aligned}
$$

\section{HASIL DAN PEMBAHASAN}

Seiring dengan meningkatnya aktivitas perdagangan, kebutuhan untuk memberikan informasi mengenai perkembangan bursa juga semakin meningkat. Salah satu informasi yang diperlukan tersebut adalah indeks harga saham sebagai cerminan dari pergerakan harga saham.

Perkembangan IHSG pada tahun 2014m1-2018m3 berfluktuatif. Nilai tertinggi IHSG menembus angka 5518 pada tahun $2015 \mathrm{~m} 3$ dan terendah diangka 4223 pada tahun $2015 \mathrm{~m} 9$.

\section{Uji Kriteria Statistik Akaike Information Criterion (AIC)}

Langkah awal sebelum menganalis lebih jauh adalah dengan pemilihan model empirik yang tepat. Pemilihan model empirik yang digunakan adalah metode AIC. Apabila nilai AIC model pertama lebih besar dari model kedua, dimana model kedua adalah model pertama dengan penambahan 1 variabel bebas lagi, maka model kedua adalah model yang tepat. Dan apabila nilai AIC model ketiga, dimana model ketiga adalah model kedua dengan penambahan 1 variabel bebas lagi, maka model ketiga adalah model yang tepat. Begitu seterusnya, apabila model yang terbaru nilai AIC nya lebih kecil, maka penambahan variabel dapat diterima. 


\begin{tabular}{|c|c|c|c|}
\hline \multirow{2}{*}{$\begin{array}{c}\text { Model/ } \\
\text { Langkah }\end{array}$} & \multirow[b]{2}{*}{ Variabel } & \multicolumn{2}{|c|}{ Nilai AIC } \\
\hline & & $\begin{array}{l}\text { Persamaan } \\
\text { Linier }\end{array}$ & $\begin{array}{l}\text { Persamaan } \\
\text { Log Linier }\end{array}$ \\
\hline I & $\begin{array}{l}\text { Konstanta } \\
\text { X1 = Kurs }\end{array}$ & 101673,41 & 0.00430 \\
\hline II & $\begin{array}{l}\text { Konstanta } \\
\text { X1 = Kurs } \\
\text { X2= Inflasi }\end{array}$ & 101412,83 & 0.00427 \\
\hline III & $\begin{array}{l}\text { Konstanta } \\
\text { X1 = Kurs } \\
\text { X2= Inflasi } \\
\text { X3= Dummy }\end{array}$ & 68647,90 & 0.00250 \\
\hline IV & $\begin{array}{l}\text { Konstanta } \\
\text { X1 = Kurs } \\
\text { X2= Inflasi } \\
\text { X3= Dummy } \\
\text { X4=Suku } \\
\text { Bunga }\end{array}$ & 61931,64 & 0.00264 \\
\hline
\end{tabular}

Dari tabel diatas diketahui bahwa nilai Akaike Information Criterion (AIC) untuk persamaan linier, model pertama lebih besar dari model kedua dan seterusnya maka tambahan variabel baru dapat diterima. Namun tidak berlaku untuk persamaan log linear.

Untuk model ke IV pada persamaan linier kriteria statistik AIC terpenuhi Berdasarkan pemilihan model empirik dengan kriteria statistik Akaike Information Criterion (AIC), maka variabel-variabel yang layak dimasukkan dalam penelitian ini adalah Kurs, Inflasi, Dummy dan Suku Bunga Bank Indonesia (SBI).

Pemilihan Bentuk Model Empirik uji Mackinnon, White dan Davidson (uji MWD)

Dalam analisis ini, sebelum menentukan akan menggunakan persamaan linier atau log linier maka harus mengetahui apakah perilaku data menunjukkan hubungan linier atau log linier dengan metode Mackinnon, White dan Davidson (uji MWD). Kriteria pengujian ini adalah apabila $Z_{1}$ signifikan secara statistik melalui uji $\mathrm{t}$ maka kita menolak hipotesis nol bahwa model yang benar adalah model linier dan sebaliknya jika tidak signifikan maka kita menerima hipotesis nol bahwa model yang benar adalah model linier. Jika $\boldsymbol{Z}_{\mathbf{2}}$ signifikan secara statistik melalui uji $\mathrm{t}$ maka kita menolak hipotesis alternatif dan model yang benar adalah model log linier dan sebaliknya jika tidak signifikan maka kita menerima hipotesis alternatif dan model yang benar adalah model log linier.

Tabel 2

Hasil Uji Mackinnon, White dan Davidson (MWD)

\begin{tabular}{ccl}
\hline \hline Variabel & t-statistic & Prob \\
\hline \hline $\boldsymbol{Z}_{\mathbf{1}}$ & 1.473046 & 0.1527 \\
\hline $\boldsymbol{Z}_{\mathbf{2}}$ & -2.057985 & 0.0497 \\
\hline \hline
\end{tabular}

Berdasarkan hasil uji MWD diatas diketahui nilai prob $Z_{1}$ sebesar 0.1527 
lebih besar dari 0,05, maka terima Ho yang berarti model yang benar adalah model linier. Sedangkan nilai prob $\boldsymbol{Z}_{\mathbf{2}}$ sebesar 0.0497 lebih kecil dari 0.05 , maka tolak Ho yang berarti model yang benar adalah bukan model log linier. Kesimpulan dalam pemilihan model empirik dalam penelitian ini, model linier lebih tepat digunakan dalam penelitian ini.

\section{Hasil Analisis Regresi}

Untuk melihat pengaruh variabel independen terhadap variabel dependen, maka regresi yang digunakan adalah regresi linear berganda biasa dengan metode Ordinary Least Square (OLS) menggunakan data bulanan 2014.1 sampai 2018.3. Dengan metode tersebut dapat dilihat dan dianalisis pengaruh variabel Kurs, Inflasi dan Suku Bunga terhadap IHSG. Secara umum model persamaan linear ditulis sebagai berikut :

$$
\begin{gathered}
Y=\beta_{0}+\beta_{1} X_{1}+\beta_{2} X_{2}+\beta_{3} X_{3}+\beta_{4} . X_{4} \\
I H S G=\beta_{0}+\beta_{1} . K U R S+\beta_{2} . I N F L A S I \\
+\beta_{3} . D U M M Y+\beta_{4} . S_{B I}
\end{gathered}
$$

Keterangan :

$$
\begin{aligned}
\boldsymbol{Y}= & \text { IHSG (point) } \\
\boldsymbol{X}_{\mathbf{1}}= & \text { Kurs dollar US terhadap rupiah } \\
& \text { (rupiah) } \\
\boldsymbol{X}_{\mathbf{2}}= & \text { Inflasi }(\%) \\
\boldsymbol{X}_{\mathbf{3}}= & \text { Dummy } \\
\boldsymbol{X}_{\mathbf{4}}= & \text { Suku Bunga }(\%)
\end{aligned}
$$

Berdasarkan hasil output, maka didapat persamaan faktor-faktor yang memengaruhi IHSG di Bursa Efek Indonesia selama periode 2014.1 -2018.3 sebagai berikut:

IHSG $=10586,69-0,500318 K U R S-$ 61,26270INFLASI + 782,1512DUMMY + 77,14557SBI

Dimana

$$
\begin{aligned}
\text { IHSG }= & \text { IHSG di Bursa Efek Indonesia } \\
& \text { periode 2014.1 }-2018.3 \text { (point) } \\
K U R S= & \text { Kurs dollar US terhadap rupiah } \\
& \text { periode 2014.1 -2018.3 (rupiah) }
\end{aligned}
$$

$I N F L A S I=$ Inflasi bulanan periode 2014.1 $-2018.3(\%)$

$D U M M Y=$ Dummy Variabel,

$0=$ sebelum pengumuman kabinet kerja Joko Widodo,

1 = setelahnya.

SBI $=$ Suku Bunga Bank Indonesia bulanan periode 2014.1 - $2018.3(\%)$

\section{Uji t Statistik}

Hal ini dilakukan dengan cara pengujian variabel-variabel independent secara parsial (individu), digunakan untuk mengetahui signifikasi dan pengaruh variabel independent secara individu terhadap variasi terhadap variabel independent lainnya.

Uji ini dilakukan dengan membandingkan nilai $t$-statistic (thitung) dengan nilai ( $\boldsymbol{t}_{\text {tabel }}$ ) atau membandingkan nilai probabilitasnya dengan derajat signifikansinya pada tingkat keyakinan

\begin{tabular}{|c|c|c|c|}
\hline Variabel & $t$-statistic & Probabilitas & Kesimpulan \\
\hline KURS & $\begin{array}{l}- \\
5.650797\end{array}$ & 0.0000 & $\begin{array}{l}\text { Signifikan } \\
\text { pada } \alpha=0,05\end{array}$ \\
\hline INFLASI & $\begin{array}{l}- \\
1.702629\end{array}$ & 0.1001 & $\begin{array}{l}\text { Tidak } \\
\text { Signifikan } \\
\text { pada } \alpha=0,05\end{array}$ \\
\hline DUMMY & 4.798250 & 0.0001 & $\begin{array}{l}\text { Signifikan } \\
\text { pada } \alpha=0,05\end{array}$ \\
\hline SBI & 0.466289 & 0.6447 & $\begin{array}{l}\text { Tidak } \\
\text { Signifikan } \\
\text { pada } \alpha=0,05\end{array}$ \\
\hline
\end{tabular}
95\% atau pada derajat signifikansi sebesar $5 \%(\alpha=0,05)$. Jika nilai ( $\left.\boldsymbol{t}_{\text {hitung }}\right)$ lebih besar dari t table $\left(\boldsymbol{t}_{\text {hitung }}>\boldsymbol{t}_{\text {tabe }}\right)$ atau nilai probabilitasnya lebih kecil dari 5\% (p < 0,05), maka variabel independen secara individu berpengaruh signifikan terhadap variabel dependen.

Berdasarkan output dari eviews maka dapat diperoleh kesimpulan sebagai berikut :

Tabel 4.

Hasil Uji Parsial/Uji t 
Variabel Kurs, signifikan pada tingkat $\alpha=0,05$ yang berarti kurs berpengaruh terhadap IHSG.

Variabel Inflasi, tidak signifikan pada tingkat $\alpha=0,05$ yang berarti inflasi berpengaruh terhadap IHSG namun tidak signifikan. Variabel Dummy, signifikan pada tingkat $\alpha=0,05$ yang berarti Dummy berpengaruh terhadap IHSG. Variabel SBI, tidak signifikan pada tingkat $\alpha=0,05$ yang berarti SBI berpengaruh terhadap IHSG namun tidak signifikan.

\section{Uji F}

F-statistik menggambarkan hasil analisa regresi variabel independent secara bersama-sama terhadap variabel dependent. Dengan kata lain pengujian terhadap variabel - variabel independent secara bersama-sama yang dilakukan untuk melihat pengaruh variabel independent secara individu terhadap variabel dependent.

Uji ini dilakukan dengan membandingkan nilai $\boldsymbol{F}_{\text {statistic }} \quad\left(\boldsymbol{F}_{\text {hitung }}\right)$ dengan nilai $\boldsymbol{F}_{\text {tabel }}$ atau membandingkan nilai probabilitasnya dengan derajat signifikansinya pada tingkat keyakinan 95\% atau pada derajat signifikansi sebesar 5\% $(\alpha=0,05)$. Jika nilai $\boldsymbol{F}_{\text {hitung }}$ lebih besar dari nilai $\boldsymbol{F}_{\text {hitung }}\left(\boldsymbol{F}_{\text {hitung }}>\boldsymbol{F}_{\text {tabel }}\right)$ atau nilai probabilitasnya lebih kecil dari 5\% (p < 0,05), maka variabel independen secara bersama-sama berpengaruh signifikan terhadap variabel dependen.

\begin{tabular}{llll}
\hline \hline Variabel & $\begin{array}{c}\text { F- } \\
\text { statistic }\end{array}$ & Probabilitas Kesimpulan \\
\hline \hline KURS & & & Signifikan \\
& & & pada \\
INFLASI & 8.29941 & 0.000168 & $\alpha=5 \%$ \\
DUMMY & 9 & & \\
SBI & & & \\
\hline \hline
\end{tabular}

Dari hasil analisa menunjukkan bahwa F hitung sebesar 8.299419 dan dengan probabilitas 0.000168 , dengan tingkat $\alpha=0,05$, dapat dilihat bahwa probabilitasnya lebih kecil dari $\alpha$ yaitu $0.000168<0,05$, dengan demikian variabel independent secara bersama-sama berpengaruh signifikan terhadap variabel dependent. Variabel Kurs, inflasi, Dummy, SBI secara bersama-sama berpengaruh signifikan terhadap variabel IHSG.

\section{Uji Koefisien Determinasi $\left(\boldsymbol{R}_{2}\right)$}

Nilai $\left(\boldsymbol{R}_{\mathbf{2}}\right)$ koefisien determinasi dilakukan untuk melihat seberapa besar variabel independent berpengaruh terhadap variabel dependen. Nilai $\left(\boldsymbol{R}_{\boldsymbol{2}}\right)$ antara $0-1$. Nilai $\left(\boldsymbol{R}_{\boldsymbol{2}}\right.$ makin mendekati 0 maka pengaruh semua variabel independent terhadap variabel dependen makin kecil dan sebaliknya nilai $\left(\boldsymbol{R}_{2}\right)$ makin mendekati 1 maka pengaruh semua variabel independent terhadap variabel dependent makin besar.

Dari hasil regresi linier berganda diperoleh nilai $\left(\boldsymbol{R}_{2}\right)$ sebesar 0.551478 yang berarti variasi variabel jumlah uang beredar M2, kurs, inflasi dan suku bunga memengaruhi variabel IHSG sebesar $55,15 \%$. Sedangkan sisanya $44,85 \%$ dijelaskan oleh variabel lain yang tidak dianalisis dalam model regresi ini.

\section{SIMPULAN}

Berdasarkan hasil dan pembahasan maka diperoleh kesimpulan sebagai berikut:

Kurs mempunyai pengaruh yang negatif terhadap IHSG, dengan koefisien regresi sebesar -0,5000318 yang artinya jika perubahan kurs naik sebesar satu rupiah, maka perubahan variabel IHSG akan menurun sebesar 0,5000318 point. 
Peningkatan kurs maka akan diikuti dengan penurunan IHSG.

Inflasi mempunyai pengaruh yang negatif terhadap IHSG, dengan koefisien regresi sebesar -61,26270 yang artinya jika perubahan inflasi naik sebesar satu persen, maka perubahan variabel IHSG akan menurun sebesar 61,26270 point. Peningkatan inflasi maka akan diikuti dengan penurunan IHSG

Berdasarkan hasil regresi, variabel Dummy mempunyai pengaruh yang positif terhadap IHSG, dengan koefisien regresi sebesar 782,1512. Dengan demikian, setelah pengumuman kabinet kerja Joko Widodo, IHSG mengalami perubahan peningkatan sebesar 782,1512 point (Ceteris paribus). Ini berarti terdapat korelasi positif antara dummy variabel dan IHSG.

Suku bunga mempunyai pengaruh yang positif terhadap IHSG, dengan koefisien regresi sebesar 77,14557 artinya jika perubahan suku bunga naik sebesar satu persen, maka perubahan variabel IHSG akan meningkat sebesar 77,14557 point (Ceteris paribus). Ini berarti terdapat korelasi positif antara suku bunga dan IHSG

Nilai $\left(R_{2}\right)$ sebesar 0.55147 yang berarti variasi variabel kurs, inflasi, dummy dan suku bunga memengaruhi variabel IHSG sebesar 55,15\%. Sedangkan sisanya $44,85 \%$ dijelaskan oleh variabel lain yang tidak dianalisis dalam model regresi ini.

\section{Saran}

1. Sebaiknya otoritas moneter dalam mengendalikan IHSG memprioritaskan pada kebijakan stabilitas nilai tukar/kurs, inflasi sehingga memperkuat pengendalian dan stabilitas saham di pasar BEI. Pemerintah sebaiknya menaikkan suku bunga SBI agar memperkuat IHSG dan stabilitas saham di pasar BEI.

2. Pemerintah sebaiknya berusaha menjaga stabilitas perekonomian untuk menghindari.

\section{DAFTAR PUSTAKA}

Ardiono, Angga Rahmat, 2008, Analisis Faktor - Faktor yang Mempengaruhi Inflasi di Indonesia Tahun 1990.1 - 2005.4, Skripsi, Fakultas Ekonomi, Universitas Islam Indonesia

Gujarati, 2003, Ekonometri Dasar, Jakarta, Erlangga

Husnan, Suad, 2000, Manajemen Keuangan dan Teori (Keputusan Jangka Panjang, Yogyakarta, BPFE UGM

Hardoko, Ervan, "Universitas Melbourne Bahas "Jokowi Effect",", http://internasional.kompas.com/read/2014/04/15/1637137/Universitas.Melbourne.B ahas.Jokowi.Effect, Diakses tanggal 3 April 2018

Nailiu, Bernardinus A, 2015, Pengaruh Pengumuman Pencapresan Jokowi 2014 Di Bursa Efek Indonesia (Event Study: "Jokowi Effect" Pada Saham LQ45), Yogyakarta, Universitas Atmajaya

Oktavilia, Shanty, 2003, Analisis Pengaruh Variabel Ekonomi Makro Terhadap Perkembangan Harga Saham di BEJ Periode 1990 - 2000, Skripsi, Universitas Diponegoro 
Sari, Putri Novita, 2015, Pengaruh Pengumuman Kabinet Kerja Joko Widodo Terhadap Perubahan Reaksi Pasar Modal Pada Perusahaan Manufaktur Di Bursa Efek Indonesia, Surakarta, Universitas Muhammadiyah Surakarta

Susanti, Anisa, 2015, Analisis Pengaruh Kemenangan Pasangan Joko Widodo Jusuf Kalla dalam Pilpres 2014 terhadap Abnormal Return dan Trading Volume Activity pada Kelompok Saham Indeks LQ4, Skripsi, Fakultas Ekonomi, Universitas Negeri Yogyakarta

Sukirno, Sadono, 2006, Teori Ekonomi Mikro, Jakarta, PT Raja Grafindo Persada.

Sukirno, Sadono, 2000, Makroekonomi Modern, Jakarta, PT Raja Grafindo Persada.

Suryawijaya, Marwan Asri, dkk, 2002, Reaksi Pasar Modal Indonesia Terhadap Peristiwa Politik Dalam Negeri (Event Study Pada Peristiwa 27 Juli 1996)”, Bunga Rampai Kajian Teori Keuangan, Yogyakarta, BPFE

Tri Wibowo, Arinto (14 March 2014)."Jokowi Capres, Indeks Saham Melesat" VivaNews. Diakses 10 Maret 2018

Walpole, Ronald. E, 1995, Pengantar Statistika, Jakarta, Gramedia Pustaka Utama.

Widarjono, Agus, 2007, Ekonometrika : Teori dan Aplikasi untuk Ekonomi dan Bisnis, Yogyakarta, Ekononisia UII.

Zaqi, Mochamad, 2006. "Reaksi Pasar Modal Indonesia Terhadap Peristiwa-peristiwa Ekonomi dan Peristiwa-peristiwa Politik Dalam Negeri (Study pada Saham LQ45 di BEJ Periode 1999-2003)".Tesis, Magister Manajemen, Universitas Diponegoro, Semarang 